\title{
Vasopressin Stimulates Na-dependent Phosphate Transport and Calcification in Rat Aortic Smooth Muscle Cells
}

\author{
KEIKO NISHIWAKI-YASUDA*,**, ATSUSHI SUZUKI*, AYAKO KAKITA**, SAHOKO SEKIGUCHI*, \\ SHOGO ASANO*, KAZUHIRO NISHII***, SHIZUKO NAGAO***, YUTAKA OISO** AND MITSUYASU ITOH* \\ *Division of Endocrinology and Metabolism, Department of Internal Medicine, Fujita Health University School of Medicine, 1-98 \\ Dengakugakubo, Kutsukake-cho, Toyoake, Aichi 470-1192, Japan \\ **Department of Endocrinology and Diabetes, Nagoya University Graduate School of Medicine, Nagoya 466-8550, Japan \\ ***Education and Research Center of Animal Models for Human Diseases, Fujita Health University, Toyoake, Aichi 470-1192, Japan
}

\begin{abstract}
We investigated the effect of arginine vasopressin (AVP) on inorganic phosphate (Pi) transport in A-10 rat aortic vascular smooth muscle cells (VSMCs). AVP time- and dose-dependently stimulated Na-dependent Pi transport in A-10 cells. This stimulatory effect of AVP on Pi transport was markedly suppressed by V1 receptor antagonist. A protein kinase C (PKC) inhibitor calphostin C partially suppressed the stimulatory effect of AVP. The selective inhibitors of cJun- $\mathrm{NH}_{2}$-terminal mitogen-activated protein (MAP) kinase (Jun kinase) attenuated AVP-induced Pi transport, but Erk kinase or p38 MAP kinase inhibitors did not. Wortmannin, a phosphatidylinositol (PI) 3-kinase inhibitor, suppressed AVP-induced Pi transport. Rapamycin, a selective inhibitor of $\mathrm{S}_{6}$ kinase, reduced this effect of AVP, while Akt kinase inhibitor did not. The combination of inhibitors for PKC, Jun kinase and PI 3-kinase completely suppressed the AVPenhanced Pi transport. Furthermore, AVP rescued the VSMC from high phosphate-induced cell death and enhanced mineralization of these cells. In summary, these results suggest that AVP stimulates both Na-dependent Pi transport and mineralization in VSMCs. The mechanism is mediated by the activation of multiple signaling pathways including PKC, PI 3-kinase, $\mathrm{S}_{6}$ kinase and Jun kinase.
\end{abstract}

Key words: Vascular smooth muscle cells, Inorganic phosphate transport, Arginine vasopressin

(Endocrine Journal 54: 103-112, 2007)

VASCULAR calcification is often encountered in the development of atherosclerotic lesions [1]. Until recently, vascular calcification was considered to be a passive, degenerative, end-stage process of vascular disease. However, a recent study by Jono et al. [2] suggests that aortic vascular smooth muscle cell (VSMC) acquires the phenotype of osteoblast-like cells, and that the expression of inorganic phosphate transporter (PiT) on VSMC is important in the process of vascular calcification. The enhancement of Pi transport in boneforming cells is essential for the mineralization of

Received: June 2, 2006

Accepted: October 13, 2006

Correspondence to: Atsushi SUZUKI, M.D., Ph.D., Division of Endocrinology and Metabolism, Department of Internal Medicine, Fujita Health University, 1-98 Dengakugakubo, Kutsukake, Toyoake, Aichi 470-1192, Japan skeletal tissues [3], and several growth factors and hormones have been reported to stimulate both proliferation and Pi transport [4-7]. As for VSMCs, it is nowadays well accepted that the proliferation of VSMC plays a crucial role in the pathogenesis of hypertension and atherosclerosis, and is a key event during the formation of intimal hyperplasia after artery injury $[1,8]$. After vascular injury, VSMC at the artery media is activated and migrates to the intima, where the cells proliferate and secrete extracellular matrix components [1]. We have recently reported that platelet-derived growth factor (PDGF) stimulates Pi transport activity through the expression of type III Na-dependent PiT, which is considered to be essential for the mineralization of bone tissues [3,9], in rat A-10 aortic VSMC [10]. However, the precise mechanism of the enhancement of Pi transport activity by extracellular stimuli in VSMC has yet to be fully elucidated. 
Arginine vasopressin (AVP) plays a major role in the regulation of body fluid volume, and exerts potent vasoconstrictor action [11]. In vitro, AVP has been reported to stimulate the proliferation of VSMCs $[12,13]$. There are at least three subtypes of heterotrimeric GTP-binding protein-coupled receptors (GPCRs) which bind to AVP, V1a, V1b and V2 [14]. V1a receptor is located mainly in the central nervous system and cardiovascular organs including VSMC, while V1b and V2 are located in the central nervous system and kidney, respectively. As for intracellular signaling mechanisms, it has been reported that AVP mobilizes intracellular $\mathrm{Ca}^{2+}$ and stimulates protein kinase $\mathrm{C}$ (PKC) through the activation of phospholipase (PL) C and PLD in VSMC [15-17], which is involved in the mechanism of AVP-induced proliferation of these cells [18]. Other important signaling pathways to mediate the mitogenic and differentiation processes are tyrosine kinases. It has been reported that AVP also stimulated tyrosine kinases in VSMC [19], and that AVPstimulated cell proliferation was mediated by the activation of extracellular signal-regulated kinase (ERK) mitogen-activated protein (MAP) kinase and $\mathrm{S}_{6}$ kinase in glomerular mesangial cells [20]. In the present study, we investigated the effect of AVP on Pi transport system in rat A-10 VSMCs to gain more insight into the mechanism of vascular calcification.

\section{Materials and Methods}

\section{Chemicals}

Cell culture reagents were purchased from ICN Biochemicals, Inc. (Costa Mesa, CA, USA). Fetal calf serum (FCS), glutamine, antibiotics and trypsin/EDTA were from Gibco Life Technologies Ltd. (Paisley, UK). AVP and [Pmp $\left.{ }^{1}, \operatorname{Tyr}(\mathrm{Me})^{2}\right]-$ Arg $^{8}$-vasopressin (V1 receptor antagonist) were purchased from Peptide Institute, Inc., (Minoh, Japan). Calphostin C, 1,4-diamino-2,3-dicyano-1,4-bis(2-aminophenylthio)butadiene (U0126), 4-(4-fluorophenyl)-2-(4-methylsulfinylphenyl)5-(4-pyridyl) 1H-imidazole (SB203580), anthra(i,gcd)pyrazol-6(2H)one (SP600125), wortmannin, 1L-6hydroxymethyl-chiro-inositol 2-(R)-2-O-methyl-3-Ooctadecylcarbonate (Akt inhibitor), and rapamycin were obtained from Calbiochem-Novabiochem (La Jolla, CA, USA). Apoptosis in situ detection kit was from Wako Chemicals Co. (Osaka, Japan). $\left.\mathrm{H}_{3}{ }^{[32} \mathrm{P}\right] \mathrm{O}_{4}$ was from DuPont de Nemours (Brussels, Belgium). ${ }^{45} \mathrm{CaCl}_{2}$ was from Amersham Pharmacia Biotech (Little Chalfont, UK). All other chemicals were from standard laboratory suppliers and were of the highest purity commercially available.

\section{Cell culture}

Cloned aortic smooth muscle A-10 cells derived from embryonic rat were purchased from American Type Culture Collection (Manassas, VA, USA). The cells were grown in Dulbecco's modified Eagle's medium (DMEM) containing 10\% FCS, $100 \mathrm{IU} / \mathrm{ml}$ penicillin and $100 \mu \mathrm{g} / \mathrm{ml}$ streptomycin. Subcultures were obtained twice a week by using $0.25 \%$ trypsin in $\mathrm{Ca}^{2+}$ and $\mathrm{Mg}^{2+}$ - free Eagle's salt solution that contained $0.02 \%$ EDTA. They were seeded at $10,000 \mathrm{cells} / \mathrm{cm}^{2}$ and cultures were maintained at $37^{\circ} \mathrm{C}$ in a humidified atmosphere of $5 \% \mathrm{CO}_{2}-95 \%$ air. As for the experiments of $\mathrm{Ca}$ acquisition, the cells were seeded on type I-collagen precoated plates.

\section{Influence of AVP on Pi transport activity}

The effect of AVP on Pi transport was analyzed in confluent A-10 cells cultured in DMEM containing 2\% FCS for $24 \mathrm{~h}$. Unless specified, they were then incubated for $6 \mathrm{~h}$ in the same culture medium with either various doses of AVP or its vehicle. Following cells treatment with agents, Pi transport activity was determined in Earle's buffered salt solution (EBSS) containing $0.1 \mu \mathrm{M}$ labeled $\mathrm{H}_{3}\left[{ }^{32} \mathrm{P}\right] \mathrm{O}_{4}$ as previously described [4]. Before the transport assay, the cell layer was rinsed three times with EBSS without radioactive or cold substrate. The transport measurement started after adding $0.3 \mathrm{ml}$ of EBSS containing the labeled substrate $(1 \mu \mathrm{Ci} / \mathrm{ml})$. After $10 \mathrm{~min}$ incubation, the uptake solution was aspirated, and the cell layer was rinsed three times with $0.3 \mathrm{ml}$ of ice-cold substrate free EBSS. At the end of the experiment, cells were solubilized with $0.25 \mathrm{ml}$ of $0.2 \mathrm{~N}$ sodium hydroxide and the radioactivity contained in $200 \mu \mathrm{l}$ aliquot was counted by using a standard liquid scintillation technique. Finally, the radioactivity in each well was adjusted by DNA content of the cells treated with same protocol as Pi transport activity was measured. Preliminary experiments indicated that Na-independent component of Pi transport in A-10 cells was less than $10 \%$ of total uptake of $\mathrm{Pi}$ determined in the presence of $143 \mathrm{mM}$ choline chloride 
and this component was not influenced by AVP (data not shown). Therefore this sodium-independent component was neglected in this study.

\section{Alizarin red staining}

Confluent A-10 cells (day 8) were treated with $0.1 \mu \mathrm{M}$ of AVP or its vehicle every other day in DMEM containing 10\% FCS and $1.6 \mathrm{mM} \mathrm{NaH} \mathrm{PO}_{4}$. The final concentration of extracellular Pi was $2.5 \mathrm{mM}$. At day 14, mineralized nodules were determined by alizarin red staining.

\section{Effect of AVP on the Ca deposition on A-10 cells}

Confluent A-10 cells were cultured in DMEM containing $10 \% \mathrm{FCS}$ and $1.6 \mathrm{mM} \mathrm{NaH} \mathrm{PO}_{4}$ for indicated periods. The final concentration of extracellular Pi was $2.5 \mathrm{mM}$. The medium was exchanged with or without $0.1 \mu \mathrm{M}$ AVP every other day. At day 8 and 14, Ca deposition was determined in assay buffer $(5 \mathrm{mM} 4-(2-$ hydroxyethyl)-1-piperazineethane sulfonic acid, $\mathrm{pH} 7.4$, $150 \mathrm{mM} \mathrm{NaCl}, 5 \mathrm{mM} \mathrm{KCl}, 5.5 \mathrm{mM}$ glucose, $0.8 \mathrm{mM}$ $\mathrm{MgSO}_{4}$ and $1 \mathrm{mM} \mathrm{CaCl}_{2}$ with $1 \mu \mathrm{Ci} / \mathrm{ml}^{45} \mathrm{CaCl}_{2}$ ). After $24 \mathrm{~h}$ incubation, the solution was aspirated. Before the assay, the cell layer was rinsed four times with $0.3 \mathrm{ml}$ of assay buffer without radioactive substrate. At the end of the experiment, ${ }^{45} \mathrm{Ca}$ accumulation in extracellular matrices was examined as previously described $[21,22]$.

\section{TUNEL assay}

Confluent A-10 cells were cultured in DMEM containing $10 \% \mathrm{FCS}$ and $1.6 \mathrm{mM} \mathrm{NaH} \mathrm{PO}_{4}$. The final concentration of extracellular $\mathrm{Pi}$ was $2.5 \mathrm{mM}$. The medium was exchanged with or without $0.1 \mu \mathrm{M}$ AVP every other day. Apoptosis was assessed by terminal deoxynucleotidyl transferase-mediated dUDP nick end-labeling (TUNEL) staining using an Apoptosis In Situ Detection kit (WAKO Pure Chemical Industries Ltd., Osaka, Japan) according to the manufacture's instructions.

\section{Statistical analysis}

Results are expressed as means \pm standard error of the mean (SEM). A two-sided unpaired Student's $t$-test or analysis of variance (ANOVA) for multiple com- parisons was used for statistical analysis. A difference between experimental groups was considered to be significant when the $P$ value was $<5 \%$.

\section{Results}

AVP dose-dependently enhanced Na-dependent Pi transport in A-10 cells. A significant effect was detected at $0.01 \mathrm{nM}$, and maximal stimulation was reached at a dose of $10 \mathrm{nM}$ (Fig. 1A). The effect was timedependent and was detected significantly after $3 \mathrm{~h}$ incubation (Fig. 1B). A maximal response was reached after $6 \mathrm{~h}$. On the contrary, AVP did not affect $\left[{ }^{3} \mathrm{H}\right]$ alanine transport in A-10 cells (data not shown).

We next explored the intracellular signaling mechanisms involved in the AVP-induced stimulation of $\mathrm{Pi}$ transport in A-10 VSMC. The pretreatment with V1 receptor antagonist $(0.1 \mu \mathrm{M})$ [23] suppressed AVP $(0.1 \mu \mathrm{M})$-induced enhancement of Pi transport (vehicle, $204 \pm 7$; AVP, $294 \pm 3$; V1 antagonist, $225 \pm 4$; $\mathrm{V} 1$ antagonist $+\mathrm{AVP}, 222 \pm 11 \mathrm{pmol} / 10 \mathrm{~min} / \mu \mathrm{gDNA}$, mean $\pm \mathrm{SEM}$ ). Calphostin $\mathrm{C}$, a potent inhibitor for PKC [24], partially suppressed AVP-induced Pi transport in A-10 cells (Table 1). MAP kinases are known as key enzymes in controlling mitogenic and differentiation processes induced by growth factors [25]. In this study, AVP-induced Pi transport was not influenced by either U0126, a specific inhibitor of ERK kinase (MEK) [26], or SB203580, a selective p38 MAP kinase inhibitor [27] in A-10 cells (Fig. 2). On the contrary, SP600125, which selectively inhibits c-Jun-NH2terminal kinases (Jun kinase) at $20 \mu \mathrm{M}$ [28], suppressed the enhancement of Pi transport in these cells (Fig. 2). The phosphatidylinositol (PI) 3-kinase pathway is another important intracellular signaling mechanism previously shown to influence the stimulation of solute transport activities in response to activated PDGF receptors in A-10 VSMC [10]. Wortmannin, a specific inhibitor of PI 3-kinase [29], significantly reduced the change in Pi transport induced by AVP in A-10 cells (Table 2). Furthermore, rapamycin, a selective inhibitor of $\mathrm{S}_{6}$ kinase [30], reduced the stimulatory effect of AVP on Pi transport in the range between 0.01 and 100 nM, while Akt inhibitor had no effect (Fig. 3). The pretreatment with a combination of three inhibitors, calphostin C, SP600125 and wortmannin, completely suppressed AVP-induced Pi transport (Table 3). A-10 VSMC cultured in high phosphate $(2.5 \mathrm{mM})$ DMEM 
A

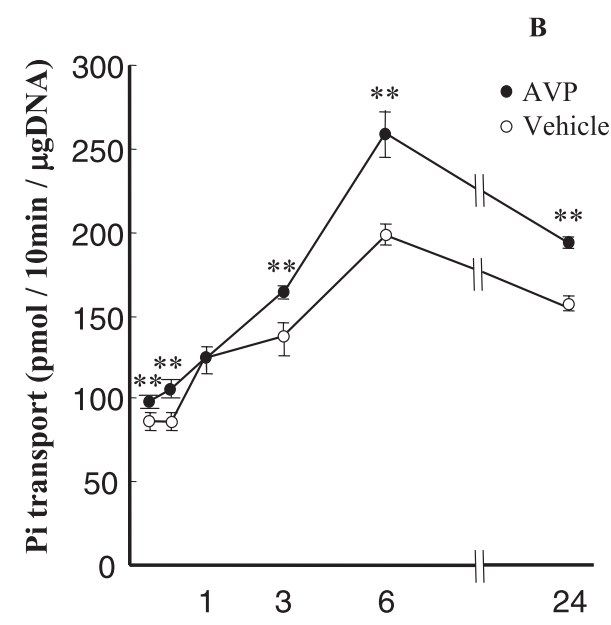

$\operatorname{AVP}(\mathrm{nM})$

Time(h)

Fig. 1. Characteristics of Pi transport stimulation incubated by arginine vasopressin (AVP) in A-10 cells. (A) Dose-dependent effect of AVP on Pi transport. Confluent A-10 cells (Day 8) were cultured in DMEM containing 2\% FCS for $24 \mathrm{~h}$, then incubated for $6 \mathrm{~h}$ with various doses of AVP. (B) Time-dependent effect of AVP on Pi transport. Confluent A-10 cells (Day 8) were cultured in DMEM containing 2\% FCS for $24 \mathrm{~h}$, then incubated with either $0.1 \mu \mathrm{M}$ of AVP $(\bullet)$ or its vehicle $(\bigcirc)$ for the indicated periods. Pi uptake was determined in EBSS containing $0.1 \mu \mathrm{M} \mathrm{H}_{3}\left[{ }^{32} \mathrm{P}\right] \mathrm{O}_{4}$. Each value represents the mean $\pm \mathrm{SEM}$ of triplicate independent cell preparations. Similar results were obtained with two additional and different cell preparations. The Na-independent component of Pi transport was less than $10 \%$ of the total uptake of Pi, and was not influenced by AVP (data not shown).

${ }^{*} p<0.05$ compared with vehicle (ANOVA, Fisher's test)

${ }^{* *} p<0.05$ compared with vehicle (unpaired Student's t-test)

Table 1. Effect of calphostin C, a protein kinase C (PKC) inhibitor, on Pi transport stimulation induced by arginine vasopressin (AVP) in A-10 cells

\begin{tabular}{lc}
\hline & Pi transport $(\mathrm{pmol} / 10 \mathrm{~min} / \mu \mathrm{gDNA})$ \\
\hline Vehicle & $204 \pm 4.8$ \\
AVP & $286.4 \pm 0.12$ \\
Calphostin C & $170.6 \pm 4.3$ \\
Calphostin C + AVP & $198.1 \pm 6.8^{*}$ \\
\hline
\end{tabular}

Confluent A-10 cells (day 8) were cultured for $24 \mathrm{~h}$ in DMEM containing $2 \%$ FCS. They were pretreated with calphostin C $(0.5 \mu \mathrm{M})$ for $1 \mathrm{~h}$, and then incubated with AVP $(0.1 \mu \mathrm{M})$ or their vehicle for $6 \mathrm{~h}$. Pi uptake was determined in EBSS containing $0.1 \mu \mathrm{M} \mathrm{H}_{3}\left[{ }^{32} \mathrm{P}_{\mathrm{O}} \mathrm{O}_{4}\right.$. Each value represents the mean $\pm \mathrm{SEM}$ of three independent cell preparations. Similar results were obtained with two additional cell preparations.

* $p<0.0001$ compared with AVP alone (ANOVA, Scheffe's test)

for 6 days showed cell death, but the treatment with $0.1 \mu \mathrm{M}$ AVP rescued the cells and enhanced the mineralization of these cells (Fig. 4A, B). TUNEL staining analysis showed that $2.5 \mathrm{mM}$ high phosphate induced apoptosis in A-10 cells (Fig. 4C), and this apoptosis was rescued by the treatment of $0.1 \mu \mathrm{M}$ AVP (Fig.
Table 2. Effects of the inhibitor of phosphatidylinositol (PI) 3kinase on Pi transport stimulation induced by arginine vasopressin (AVP) in A-10 cells

\begin{tabular}{lc}
\hline & Pi transport (pmol/10 min/ $\mu \mathrm{gDNA})$ \\
\hline Vehicle & $220.7 \pm 7.3$ \\
AVP & $296 \pm 4.2$ \\
Wortmannin & $212.9 \pm 32$ \\
Wortmannin + AVP & $233.8 \pm 4^{*}$ \\
\hline
\end{tabular}

Confluent A-10 cells (day 8) were cultured in DMEM containing $2 \%$ FCS for $24 \mathrm{~h}$. They were pretreated with $10 \mu \mathrm{M}$ of wortmannin, or their vehicle for $1 \mathrm{~h}$, and then incubated with either $0.1 \mu \mathrm{M}$ AVP or its vehicle for additional $6 \mathrm{~h}$. Pi uptake was determined in EBSS containing $0.1 \mu \mathrm{M} \mathrm{H}_{3}\left[{ }^{32} \mathrm{P}\right] \mathrm{O}_{4}$. Each value represents the mean \pm SEM of three independent cell preparations. Similar results were obtained with two additional cell preparations. ${ }^{*} p<0.05$ compared with the value of AVP alone (ANOVA, Scheffe's test)

4D). We also found that AVP enhanced ${ }^{45} \mathrm{Ca}$ accumulation according to the duration of the culture (Fig. 5). 


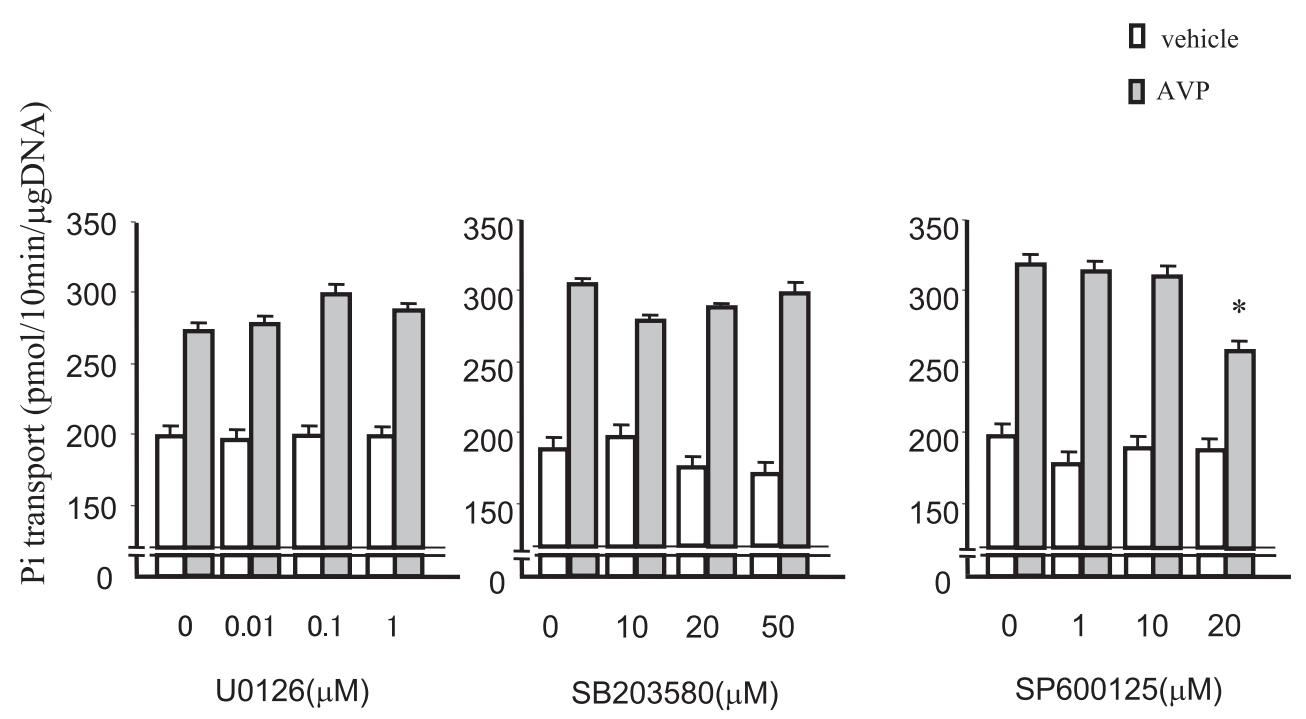

Fig. 2. Effects of MAP kinase inhibitors, U0126, a specific inhibitor of ERK kinase (MEK), SB203580, a selective p38 MAP kinase inhibitor, and SP600125, a selective inhibitor of Jun kinase, on Pi transport induced by arginine vasopressin (AVP) in A-10 cells. Confluent cells were cultured in DMEM containing 2\% FCS for $24 \mathrm{~h}$, then pretreated with various doses of U0126, SB203580, SP600125 or their vehicle for $1 \mathrm{~h}$, and then incubated with either $0.1 \mu \mathrm{M}$ AVP or its vehicle for additional $6 \mathrm{~h}$. Pi uptake was determined in EBSS containing $0.1 \mu \mathrm{M} \mathrm{H}_{3}\left[{ }^{32} \mathrm{P}\right] \mathrm{O}_{4}$. Each value represents the mean $\pm \mathrm{SEM}$ of three independent cell preparations. Similar results were obtained with two additional cell preparations.

${ }^{*} p<0.05$ compared with the value of AVP alone (ANOVA, Scheffe's test)

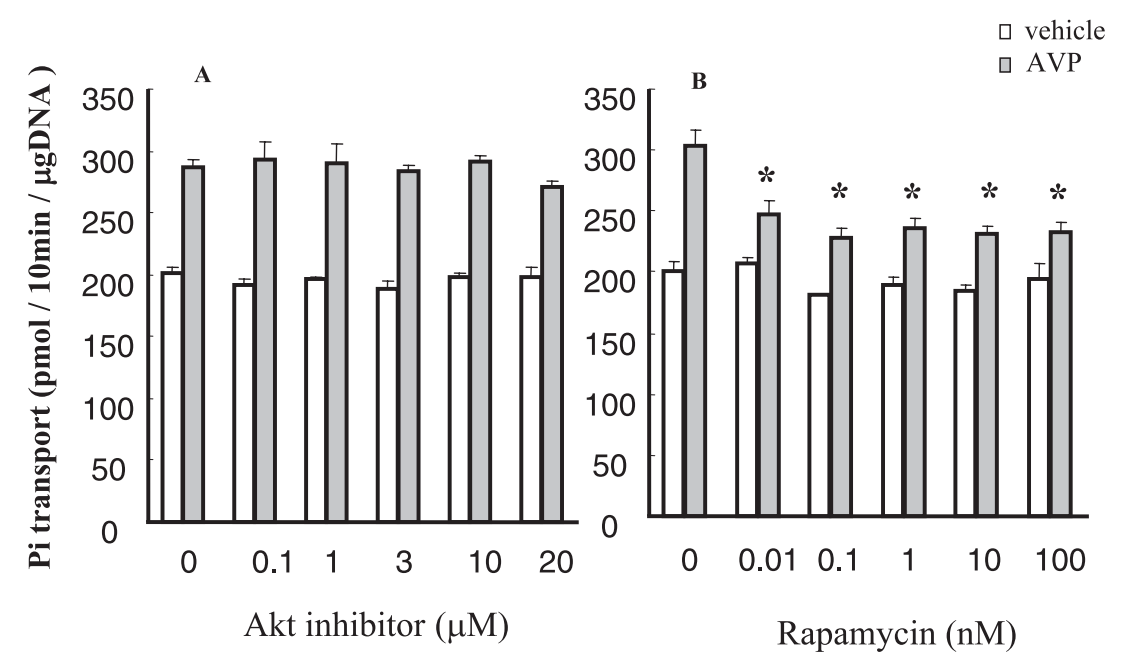

Fig. 3. Effects of Akt inhibitor (A) or rapamycin (B), on Pi transport stimulation induced by arginine vasopressin (AVP) in A-10 cells. Confluent A-10 cells (Day 8) were cultured in DMEM containing 2\% FCS for $24 \mathrm{~h}$, then pretreated with various doses of Akt inhibitor (A), rapamycin (B) or their vehicle for $1 \mathrm{~h}$, and then incubated with either $0.1 \mu \mathrm{M}$ AVP or its vehicle for additional $6 \mathrm{~h}$. Pi uptake was determined in EBSS containing $0.1 \mu \mathrm{M} \mathrm{H}_{3}\left[{ }^{32} \mathrm{P}\right] \mathrm{O}_{4}$. Each value represents the mean $\pm \mathrm{SEM}$ of three independent cell preparations. Similar results were obtained with two additional cell preparations.

${ }^{*} p<0.05$ compared with the value of AVP alone (ANOVA, Scheffe's test)

\section{Discussion}

The results of the present study indicate that AVP stimulates Na-dependent $\mathrm{Pi}$ transport activity in rat A-
10 VSMC. A significant increase of Pi transport was found just after $3 \mathrm{~h}$ stimulation by AVP. The stimulative effect of AVP was sustained for up to $24 \mathrm{~h}$, suggesting that AVP augments $\mathrm{Pi}$ transport during 
Table 3. Combined effect of calphostin C, wortmannin and SP600125 on Pi transport stimulation by arginine vasopressin (AVP) in A-10 cells

\begin{tabular}{lc}
\hline & $\%$ of control \\
\hline Control & 100 \\
AVP alone & $158.8 \pm 0.7^{*}$ \\
AVP + calphostin C & $123.2 \pm 0.1^{*}$ \\
AVP + wortmannin & $112.3 \pm 0.1^{*}$ \\
AVP + SP600125 & $125.6 \pm 0.2^{*}$ \\
AVP + calphostin C + wortmannin + SP600125 & $104.1 \pm 0.3$ \\
\hline
\end{tabular}

Confluent A-10 cells (day 8) were cultured for $24 \mathrm{~h}$ in DMEM containing $2 \%$ FCS. They were pretreated with calphostin C $(0.5 \mu \mathrm{M})$, wortmannin $(10 \mu \mathrm{M})$, SP600125 $(20 \mu \mathrm{M})$ or their combination for $1 \mathrm{~h}$, and then incubated with $\operatorname{AVP}(0.1 \mu \mathrm{M})$ or its vehicle for $6 \mathrm{~h}$. Pi uptake was determined in EBSS containing $0.1 \mu \mathrm{M} \mathrm{H}_{3}{ }^{32} \mathrm{P}^{3} \mathrm{O}_{4}$. Each value represents the mean \pm SEM of three independent cell preparations. Similar results were obtained with two additional cell preparations.

$* p<0.0001$ compared with control (ANOVA, Scheffe's test)

proliferation of VSMC. Next, we examined the intracellular signalling mechanism involved in AVP-induced stimulation of Na-dependent Pi transport in A-10 cells. AVP has been reported to show its vasoconstrictive effect through V1a receptor in cardiovascular organs including VSMC [14]. We here showed that V1 receptor antagonist attenuated the effect of AVP on Pi transport, suggesting the involvement of $\mathrm{V} 1$ receptor, possibly $\mathrm{V} 1 \mathrm{a}$, in this mechanism in VSMC.

The fact that AVP plays a protective role and supports cell survival of A-10 VSMC suggests that proliferative and/or anti-apoptotic signalling pathways are involved in the mechanism of AVP-induced Nadependent Pi transport in these cells. As AVP has been reported to stimulate proliferation through PKC activation in VSMC [18], we examined whether PKC mediates the stimulation of Pi transport by AVP in A-10 cells. We here showed that PKC inhibitor, calphostin $\mathrm{C}$, partially but significantly attenuated AVP-enhanced Pi transport in these cells, suggesting, at least in part, the involvement of PKC in the mechanism of AVP-induced enhancement of Pi transport in VSMC. Among the downstream effectors of growth factor receptor tyrosine kinases, MAP kinases are well known to be major pathways for the regulation of mitogenic and differentiation processes, including AVPinduced proliferation of VSMC, and it has been reported that AVP stimulates the activation of MAP kinases in A-10 cells [25, 31]. Three structurally related MAPK pathways have been characterized in mammalian cells.
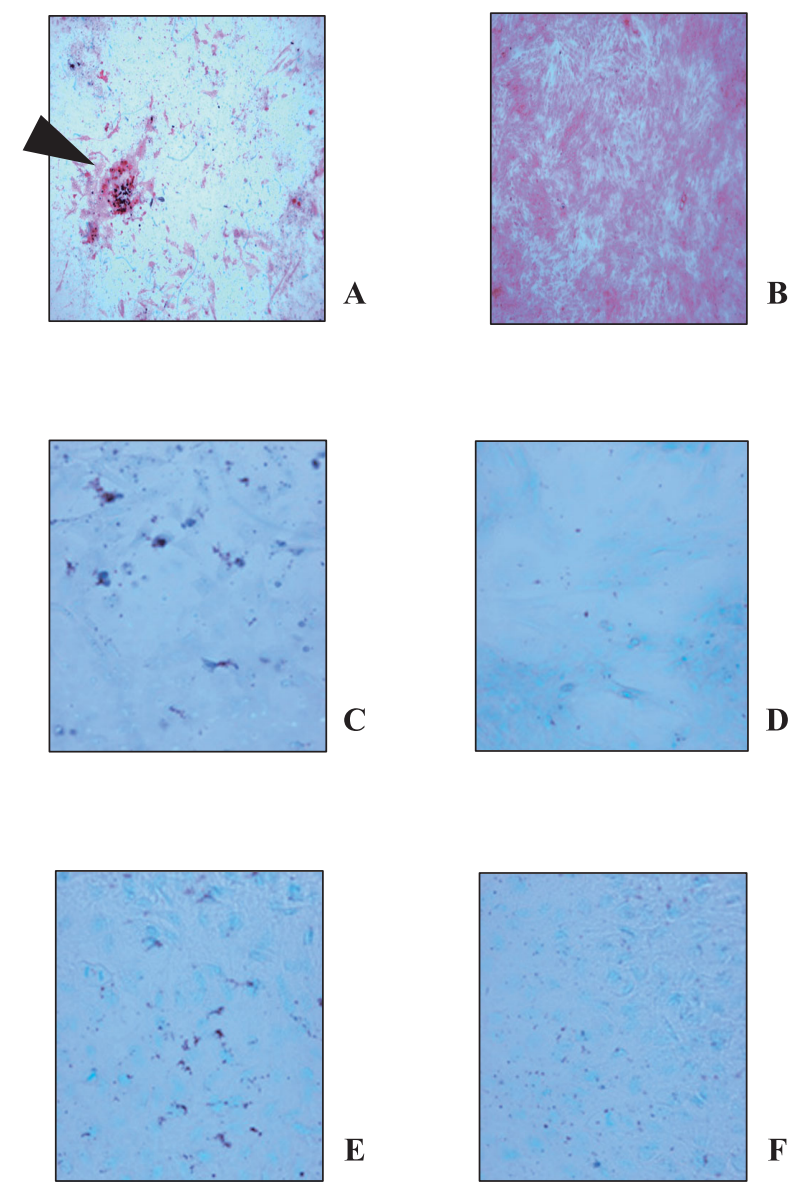

Fig. 4. Effect of arginine vasopressin (AVP) on cell survival and mineralization in A-10 cells. Confluent A-10 cells (Day 8) were cultured in DMEM containing 10\% FCS including $2.5 \mathrm{mM}$ phosphate for an additional 6 days. The medium was exchanged with or without $0.1 \mu \mathrm{M}$ AVP every other day. The Ca deposition was evaluated by alizarin red staining on day 14 (A, B). Some cells were detached from the plate and the other cells died showing the condensation of nucleus (arrow) in vehicletreated cells (A). On the other hand, AVP-treated cells at day 14 survived and showed enhanced $\mathrm{Ca}$ deposition in high phosphate media (B). At the same time, apoptosis of A-10 cells were evaluated by TUNEL assay (C, D, E, F). High phosphate medium-induced apoptosis of A-10 cells (C) was rescued by the treatment with AVP (D). Positive and negative controls of TUNEL assay were shown in $\mathrm{E}$ and $\mathrm{F}$, respectively.

The ERKs are activated downstream of cell membrane receptors and regulate cell proliferation and differentiation [32]. Jun kinase and the p38 MAPK pathways are generally activated by treatment of cells with inflammatory cytokines or by environmental stress leading to apoptosis and have therefore been named stress- 


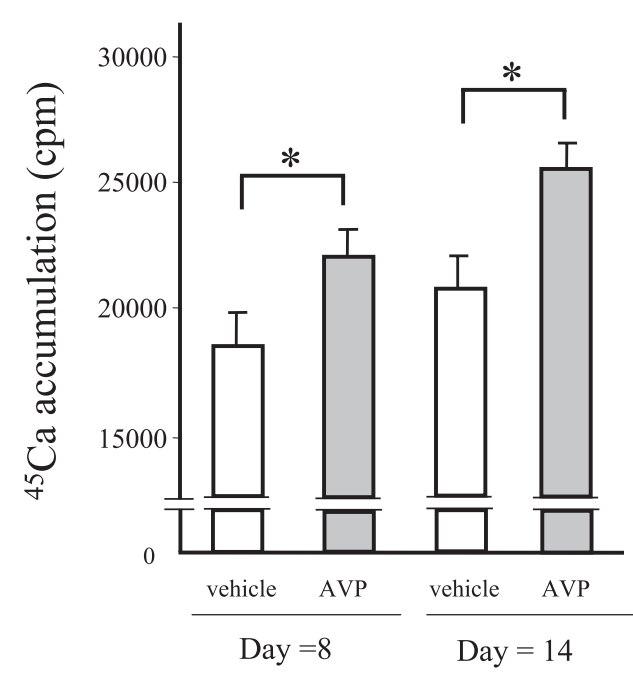

Fig. 5. The enhancement of $\mathrm{Ca}$ accumulation by arginine vasopressin (AVP) in A-10 cells. Confluent A-10 cells (Day 8) were cultured in DMEM containing $10 \%$ FCS including $2.5 \mathrm{mM}$ phosphate with or without $0.1 \mu \mathrm{M}$ AVP every the other day. On day 8 and $14,{ }^{45} \mathrm{Ca}$ accumulation for $24 \mathrm{~h}$ was detected by the method described in Materials and Methods. Each value represents the mean \pm SEM of three independent cell preparations. Similar results were obtained with two additional cell preparations.

${ }^{*} p<0.05$ compared with vehicle (ANOVA, Scheffe's test)

activated protein kinases [33]. However, accumulating evidence suggests that Jun kinase also shows antiapoptotic effect and contributes to multiple cellular processes including cell proliferation, differentiation, and cell transformation [34]. We have recently shown that Jun kinase is involved in bone morphogenetic protein-2-induced activation of both Pi transport activity and mineralization in osteoblastic cells [35]. The results obtained in this study using specific inhibitors of MEK, p38 and Jun MAP kinases suggest that not ERK or p38 MAP kinase pathways, but Jun kinase is involved in the regulation of $\mathrm{Pi}$ transport in response to AVP in VSMC. Another intracellular signalling pathway to transmit survival-promoting signals is PI 3kinase-dependent pathway. PI 3-kinase is important in particular for cell migration, actin reorganization, and prevention of cell death of apoptosis [36]. We have recently shown that PI 3-kinase and $\mathrm{S}_{6}$ kinase are involved in the mechanism of PDGF-induced enhancement of Pi transport in A-10 cells [10]. In the present study, we showed that wortmannin, a selective PI 3kinase inhibitor, significantly decreased Pi transport stimulation induced by AVP in A-10 cells. The activa- tion of PI 3-kinase phosphorylates PI to $\mathrm{D}_{3}$-phosphorylated PI, such as $\mathrm{PI}(3,4,5) \mathrm{P}_{3}$ [37]. $\mathrm{D}_{3}$-phosphorylated PI directly binds to pleckstrin-rich homology domain of several signalling molecules such as Akt and PIdependent kinase-1, which results in the activation of $\mathrm{S}_{6}$ kinase. It has recently been reported that AVPinduced HSP27 phosphorylation is mediated by PI 3kinase/Akt in A-10 VSMC [38]. In the present study, we showed that rapamycin, a selective inhibitor of $S_{6}$ kinase, reduced the stimulative effect of AVP on Pi transport in A-10 cells. On the other hand, Akt kinase inhibitor had no effect on either basal or AVP-induced Pi transport in A-10 cells. These findings suggest the PI 3-kinase and $S_{6}$ kinase also play important roles in AVP-induced enhancement of Pi transport in VSMC. Finally, we showed that the combination of the inhibitors of PKC, Jun kinase and PI 3-kinase completely suppressed AVP-induced Pi transport, suggesting their major role in this mechanism in VSMC.

Phosphate uptake at the cellular membrane is essential to maintain the cell activity because phosphate has to be supplied for ATP synthesis. Generally, the extracellular signal to stimulate cellular proliferation also induces the enhancement of phosphate uptake, that is, Pi transport activity. Growth factors are known to stimulate the proliferation through the activation of receptor tyrosine kinases in ubiquitous cells including VSMC. We have already shown that PDGF-BB, a potent stimulator of the proliferation of VSMC, enhances Pi transport activity through the increase of newlysynthesized type III NaPit, Pit-1, in A-10 VSMC [10]. In this study, we showed that AVP, a vasoactive GPCR agonist, also induces Na-dependent $\mathrm{Pi}$ transport activity during the proliferation of VSMC as well as growth factors. This enhancement of Pi transport activity is suggested to contribute to the augmentation of cellular activity and proliferation of VSMC. On the contrary, accumulating evidence suggests that phosphate overload from the extracellular milieu would be stressful for the cells, because phosphate uptake itself might induce the formation of apoptosome, resulting in the apoptosis of the cells [39]. In the present study, we found that high phosphate $(2.5 \mathrm{mM})$ induces apoptotic cell death of A-10 VSMC. However, AVP, which stimulated the proliferation of these cells in normal media (data not shown), rescued the cells from the cell death induced by high phosphate. Furthermore, we here showed that AVP enhanced the Ca deposition on A-10 VSMC in high phosphate media. Ca deposition in ex- 
tracellular matrix is considered to be regulated by $\mathrm{Pi}$ transport activity in matrix vesicles, and VSMC has been reported to produce matrix vesicles at the atherosclerotic tissues [40]. Jono et al. [2] have reported that high phosphate in extracellular milieu also induces the expression of Pit-1 Pi transporter in VSMC and its phenotypic change to osteoblastic cell. The magnitude of the enhancement of Pi transport by AVP in this study was more than $50 \%$, which we have shown to be enough to enhance the calcification of extracellular matrix in bone-forming cells in vitro [35]. These results suggest that, as well as growth factors, GPCRbinding humoral factors including AVP, which shows proliferative and/or anti-apoptotic effect on VSMC, may in turn induce calcification of artery through the enhancement of Pi transport activity of VSMC.

VSMC of the arterial media contributes to the functional and structural alteration of the arterial wall in pathophysiological process through its contractility, secretion of proteins, proliferation and migration [1]. Vasoactive humoral factors such as endothelin, angiotensin and AVP act as both systemic and local factors affecting the vascular tone and the response to the vascular injury [13]. Among them, AVP is known to be a potent vasoconstrictor that stimulates the proliferation of VSMC $[12,13,18]$. While three receptor subtypes exist for AVP (V1a, V1b and V2), V1a receptor has been reported to play the dominant role in cardiovascular system and behavior [41, 42]. It has recently been reported that V1a-/- mice showed lower blood pressure through the reduction of blood volume and the impairment of the baroreceptor reflex [42]. On the other hand, V1b-/- mice have been reported to show mildly impaired social recognition [43], but so far little information is provided on cardiovascular disorder in V1b-/- mice. These findings suggest the important role of $\mathrm{V} 1 \mathrm{a}$ receptor in maintaining resting blood pressure not by its direct vasoconstriction but by regulating neural and hormonal actions of AVP. In this study, we showed the possible involvement of $\mathrm{V} 1$ receptor in the mechanism of AVP-induced enhancement of $\mathrm{Pi}$ transport in VSMC. Because of the striking effect of AVP on body fluid retention and hyponatremia, we cannot maintain a high concentration of AVP for long duration in vivo. In addition, it has been reported that overexpression of AVP in mouse results in the downregulation of AVP receptor, and blunted the effect of AVP in vivo [44]. Although we here showed that AVP is a potent effector for both proliferation and calcification in VSMC, it seems to be difficult to prove the involvement of AVP on the progression of atherosclerosis under physiological condition in vivo. However, the elevation of serum AVP level is known to be induced by cigarette smoking, which is associated with hyperlipidemia and atherogenic changes of arteries [45]. It has also been suggested that AVP-induced hypertension causes the altered response of aorta connective tissue to vascular injury [46]. These findings as a whole suggest that elevated serum AVP level may take part in the progress of atherogenic change of arterial wall including arterial calcification under certain pathological conditions. Further investigations are required.

In conclusion, the results of the present study indicate that AVP stimulates Na-dependent Pi transport and mineralization in rat A-10 VSMCs. The mechanism is mediated by the activation of multiple signaling pathways including PKC, PI 3-kinase, $\mathrm{S}_{6}$ kinase and Jun kinase.

\section{Acknowledgements}

We are indebted to Yuko Matsumoto, Yasunaga Ono and Yoko Ishiwata for their technical help. This study was supported in part by Grant-in-Aid for Scientific Research from the Ministry of Education, Culture, Sports, Science and Technology of Japan (No15590987), and by the Nitto Foundation.

\section{References}

1. Lusis AJ (2000) Atherosclerosis. Nature 407: 233-241.

2. Jono S, McKee MD, Murry CE, Shioi A, Nishizawa Y, Mori K, Morii H, Giachelli CM (2000) Phosphate regulation of vascular smooth muscle cell calcification. Circ Res 87: e10-17.

3. Caverzasio J, Montessuit C, Bonjour JP (1996) Func- tional role of Pi transport in osteogenic cells. News Physiol Sci 11: 119-125.

4. Suzuki A, Palmer G, Bonjour JP, Caverzasio J (2000) Stimulation of sodium-dependent phosphate transport and signaling mechanisms induced by basic fibroblast growth factor in MC3T3-E1 osteoblast-like cells. $J$ 
Bone Miner Res 15: 95-102.

5. Suzuki A, Palmer G, Bonjour JP, Caverzasio J (2001) Stimulation of sodium-dependent inorganic phosphate transport by activation of $\mathrm{Gi} / \mathrm{o}$-protein-coupled receptors by epinephrine in MC3T3-E1 osteoblast-like cells. Bone 28: 589-594.

6. Masukawa H, Miura Y, Sato I, Oiso Y, Suzuki A (2001) Stimulatory effect of endothelin-1 on Na-dependent phosphate transport and its signaling mechanism in osteoblast-like cells. J Cell Biochem 83: 47-55.

7. Sato I, Suzuki A, Kakita A, Ono Y, Miura Y, Itoh M, Oiso Y (2003) Stimulatory effect of prostaglandin $F_{2 \alpha}$ on Na-dependent phosphate transport in osteoblast-like cells. Prostaglandins Leukot Essent Fatty Acids 68: 311-315.

8. Ross R (1993) The pathogenesis of atherosclerosis: a perspective for the 1990s. Nature 362: 801-809.

9. Palmer G, Guicheux J, Bonjour JP, Caverzasio J (2000) Transforming growth factor- $\beta$ stimulates inorganic phosphate transport and expression of the type III phosphate transporter Glvr-1 in chondrogenic ATDC5 cells. Endocrinology 141: 2236-2243.

10. Kakita A, Suzuki A, Nishiwaki K, Ono Y, Kotake M, Ariyoshi Y, Miura Y, Itoh M, Oiso Y (2004) Stimulation of Na-dependent phosphate transport by plateletderived growth factor in rat aortic smooth muscle cells. Atherosclerosis 174: 17-24.

11. Share L (1988) Role of vasopressin in cardiovascular regulation. Physiol Rev 68: 1248-1284.

12. Altura BM, Altura BT (1977) Vascular smooth muscle and neurohypophyseal hormones. Fed Proc 36: 18531860 .

13. Campbell-Boswell M, Robertson AL Jr (1981) Effects of angiotensin II and vasopressin on human smooth muscle cells in vitro. Exp Mol Pathol 35: 265-276.

14. Jard S, Barberis C, Audigier S, Tribollet E (1987) Neurohypophyseal hormone receptor systems in brain and periphery. Prog Brain Res 72: 173-187.

15. Miwa M, Kozawa O, Suzuki A, Watanabe Y, Shinoda J, Oiso Y (1995) Vasopressin activates phospholipase D through pertussis toxin-insensitive GTP-binding protein in aortic smooth muscle cells: function of $\mathrm{Ca}^{2+}$ /calmodulin. Biochem Cell Biol 73: 191-199.

16. Watanabe Y, Tokuda H, Suzuki A, Shinoda J, Kotoyori J, Ito Y, Oiso Y, Kozawa O (1995) Glucocorticoid amplifies vasopressin-induced phosphoinositide hydrolysis in aortic smooth muscle cells. J Cell Biochem 57: 522-529.

17. Nemenoff RA (1998) Vasopressin signaling pathways in vascular smooth muscle. Front Biosci 3: d194-d207.

18. Caramelo C, Okada K, Tsai P, Schrier RW (1989) Phorbol esters and arginine vasopressin in vascular smooth muscle cell activation. Am J Physiol 256: F875-881.

19. Gonzalez CB, Reyes CE, Figueroa CD, Barra V,
Troncoso S (1999) Vasopressin stimulates tyrosine phosphorylation by activation of PKC in the rat smooth muscle cell line, A-10. Cel Biol Int 23: 195-201.

20. Ghosh PM, Mikhailova M, Bedolla R, Kreisberg JI (2001) Arginine vasopressin stimulates mesangial cell proliferation by activating the epidermal growth factor receptor. Am J Physiol Renal Physiol 280: F972-979.

21. Warshawsky H, Moor G (1967) A technique for the fixation and decalcification of rat incisors for electron microscopy. J Histochem Cytochem 15: 542-549.

22. Kozawa O, Takatsuki K, Tokuda H, Miwa M, Kotake K, Yoneda M, Oiso Y, Saito H (1990) Insulin-like growth factor-I stimulates ${ }^{45} \mathrm{Ca}$-accumulation in cultures of osteoblast-like cells. J Bone Miner Metab 8: 161-164.

23. Kruszynski M, Lammek B, Manning M, Seto J, Haldar J, Sawyer WH (1980) [1-( $\beta$-Mercapto- $\beta, \beta$ cyclopentamethylenepropionic acid $), 2-(O$-methyl $)$ tyrosine $]$ arginine-vasopressin and $[1-(\beta$-mercapto- $\beta, \beta-$ cyclopentamethylenepropionic acid)]arginine-vasopressin, two highly potent antagonists of the vasopressor response to arginine-vasopressin. J Med Chem 23, 364-368.

24. Kobayashi E, Nakano H, Morimoto M, Tamaoki T (1989) Calphostin C (UCN-1028C), a novel microbial compound, is a highly potent and specific inhibitor of protein kinase C. Biochem Biophys Res Commun 159: 548-553.

25. Pearson G, Robinson F, Beers GT, Xu BE, Karandikar M, Berman K, Cobb MH (2001) Mitogen-activated protein (MAP) kinase pathway: regulation and physiological functions. Endocr Rev 22: 153-183.

26. Favata MF, Horiuchi KY, Manos EJ, Daulerio AJ, Stradley DA, Feeser WS, Van Dyk DE, Pitts WJ, Earl RA, Hobbs F, Copeland RA, Magolda RL, Scherle RL, Trzaskos JM (1998) Identification of a novel inhibitor of mitogen-activated protein kinase kinase. $J$ Biol Chem 273: 18623-18632.

27. Cuenda A, Rouse J, Doza YN, Meier R, Cohen P, Gallagher TF, Young PR, Lee JC (1995) SB 203580 is a specific inhibitor of a MAP kinase homologue which is stimulated by cellular stresses and interleukin-1. FEBS Lett 364: 229-233.

28. Guicheux J, Lemonnier J, Ghayor C, Suzuki A, Palmer G, Caverzasio J (2003) Activation of p38 mitogenactivated protein kinase and c-jun-NH2-terminal kinase by BMP-2 and their implication in the stimulation of osteoblastic cell differentiation. J Bone Miner Res 18: 2060-2068.

29. Nakamura I, Takahashi N, Sasaki T, Tanaka S, Udagawa N, Murakami H, Kimura K, Kabuyama Y, Kurokawa T, Suda T, Fukui Y (1995) Wortmannin, a specific inhibitor of phosphatidylinositol-3 kinase, blocks osteoclastic bone resorption. FEBS Lett 361: 79-84.

30. Terada N, Franklin RA, Lucas JJ, Blenis J, Gelfand 
EW (1993) Failure of rapamycin to block proliferation once resting cells have entered the cell cycle despite inactivation of $\mathrm{p}^{70 \mathrm{~S}_{6}}$ kinase. J Biol Chem 268: $12062-$ 12068.

31. Ito T, Kozawa $\mathrm{O}$, Tanabe $\mathrm{K}$, Niwa M, Matsuno $\mathrm{H}$, Sakai N, Ito H, Kato K, Uematsu T (2000) p38 MAP kinase is required for vasopressin-stimulated HSP27 induction in aortic smooth muscle cells. Hypertension 35: 673-678.

32. Cobb MH (1999) MAP kinase pathways. Prog Biophys Mol Biol 71: 479-500.

33. Tibbles LA, Woodgett JR (1999) The stress-activated protein kinase pathways. Cell Mol Life Sci 55: 1230 1254.

34. Ip YT, Davis RJ (1998) Signal transduction by the cjun N-terminal kinase (JNK)-from inflammation to development. Curr Opin Cell Biol 10: 205-219.

35. Suzuki A, Ghayor C, Guicheux J, Magne D, Quillard S, Kakita A, Ono Y, Miura Y, Oiso Y, Itoh M, Caverzasio J (2006) Enhanced expression of the inorganic phosphate transporter Pit-1 is involved in BMP-2-induced matrix mineralization in osteoblast-like cells. $J$ Bone Miner Res 21: 674-683.

36. Bai H, Pollman MJ, Inishi Y, Gibbons GH (1999) Regulation of vascular smooth muscle cell apoptosis. Modulation of bad by a phosphatidylinositol 3-kinasedependent pathway. Circ Res 85: 229-237.

37. Chan TO, Rittenhouse SE, Tsichlis PN (1999) AKT/ $\mathrm{PKB}$ and other D3 phosphoinositide-regulated kinases: kinases activation by phosphoinositide-dependent phosphorylation. Annu Rev Biochem 68: 965-1014.

38. Suga H, Nakajima K, Shu E, Kanno Y, Hirade K, Ishisaki A, Matsuno H, Tanabe K, Takai S, Akamatsu S, Kato K, Oiso Y, Kozawa O (2005) Possible involvement of phosphatidylinositol 3-kinase/Akt signal pathway in vasopressin-induced HSP27 phosphorylation in aortic smooth muscle A10 cells. Arch Biochem Biophys 438: $137-145$.

39. Schafer ZT, Kornbluth S (2006) The apoptosome: Physiological, developmental, and pathological modes of regulation. Dev Cell 10: 549-561.

40. Kim KM (1976) Calcification of matrix vesicles in human aortic valve and aortic media. Fed Proc 35: 156162 .

41. Bielsky IF, Hu SB, Szegda KL, Westphal H, Young LJ (2004) Profound impairment in social recognition and reduction in anxiety-like behavior in vasopressin $\mathrm{V} 1 \mathrm{a}$ receptor knockout mice. Neuropsychopharmacology 29: 483-493.

42. Koshimizu T, Nasa Y, Tanoue A, Oikawa R, Kawahara Y, Kiyono Y, Adachi T, Tanaka T, Kuwaki T, Mori T, Takeo S, Okamura H, Tsujimoto G (2006) V1a vasopressin receptors maintain normal blood pressure by regulating circulating blood volume and baroreflex sensitivity. PNAS 103: 7807-7812.

43. Wersinger SR, Ginns EL, O'Carroll A-M, Lolait SJ, Young WS III (2002) Vasopressin V1b receptor knockout reduces aggressive behavior in male mice. Mol Psychiatry 7: 975-984.

44. Tachikawa K, Yokoi H, Nagasaki H, Arima H, Murase T, Sugimura Y, Miura Y, Hirabayashi M, Oiso Y (2003) Altered cardiovascular regulation in arginine vasopressin overexpressing transgenic rat. Am J Physiol Endocrinol Metab 285: E1161-1166.

45. Krupski WC (1991) The peripheral vascular consequences of smoking. Ann Vasc Surg 5: 291-304.

46. Drobnik J, Dabrowski R, Szczepanowska A, Giernat L, Lorenc J (2000) Response of aorta connective tissue matrix to injury caused by vasopressin-induced hypertension or hypercholesterolemia. J Physiol Pharmacol 51: 521-533. 